\title{
PEMBERDAYAAN MASYARAKAT TANI MELALUI PENGENALAN PROGRAM INTEGRASI TERNAK-PADI-IKAN DI NAGARI AMPALU KECAMATAN LAREH SAGO HALABAN KABUPATEN LIMAPULUH KOTA SUMATERA BARAT
}

\author{
Purnama Dini Hari $^{1)}$ dan Wenny Surya Murtius ${ }^{2)}$ \\ Fakultas Teknologi Pertanian, Universitas Andalas \\ ${ }^{1)}$ email: purnamadini@gmail.com \\ ${ }^{2)}$ email: wenny.murtius@gmail.com
}

\begin{abstract}
ABSTRAK
Integrasi Ternak-Padi-Ikan merupakan program yang memadukan antara peternakan, pertanian dan perikanan. Program ini diharapkan dapat menunjang aktivitas pertanian dan pendapatan petani. Beberapa keuntungan yang dapat diperoleh adalah pemanfaatan kotoran ternak sebagai bahan baku pupuk organik (kompos) sebagai pupuk padi sekaligus pakan ikan, kotoran ikan yang dihasilkan dari pemeliharaan ikan di lahan sawah juga dapat dijadikan pupuk bagi tanaman padi. Ikan yang dipelihara pada lahan sawah tersebut adalah ikan nila dan padi yang ditanam adalah junjuang. Metode penyampaian program adalah andragogi, dan praktek dilakukan langsung dilahan mitra. Berdasarkan kegiatan yang telah dilaksanakan, mitra sangat antusias menerima program dan melaksanakan kegiatan secara bersama. Pengetahuan mitra mengenai program yang diberikan mengalami peningkatan berdasarkan kuisioner yang dibagikan. ALT yang terdapat pada mol (starter kompos) adalah $1,0 \times 10^{10}$ $\mathrm{CFU} / \mathrm{ml}$, kompos yang dihasilkan dimanfaatkan langsung, dan pada program mina padi terjadi kenaikan bobot ikan $40 \mathrm{~g}$ pada 10 hari pertama.
\end{abstract}

Kata Kunci: Integrasi Ternak-Padi-Ikan, Pemberdayaan, Ampalu

\section{AGRICULTURE COMMUNITY EMPOWERMENT THROUGH INTRODUCING LIVESTOCK-RICE-FISH INTEGRATION IN NAGARI AMPALU KECAMATAN LAREH SAGO HALABAN KABUPATEN LIMAPULUH KOTA SUMATERA BARAT}

\author{
Purnama Dini Hari ${ }^{1)}$ dan Wenny Surya Murtius ${ }^{2)}$ \\ Fakultas Teknologi Pertanian, Universitas Andalas \\ ${ }^{1)}$ email: purnamadini@gmail.com \\ ${ }^{2)}$ email: wenny.murtius@gmail.com
}

\begin{abstract}
The livestock-rice-fish integration is a program that combine farming, agriculture and fishery. The output of the program is to support the agriculture activity and farmers income. The advantage gained were : (1) utilization of livestock manure as a raw material of organic fertilizer (Kompos) for rice fertilizer and fish feed; and (2) the use of fish manure that farmed in rice field as rice fertilizer. The type of fish and rice used subsequently, Nile Tilapia (Oreochromis niloticus) and Junjuang. Andragogy was used as a method to deliver the program and the practice was done in partners field. Based on the completed program, partners were eager to receive the program and to perform activities collectively. Partners knowledge about the program were increasing based on questionnaires given. Total plate count (TPC) obtained from Mol (Kompos starter) was $1,0 \times 10^{10} \mathrm{CFU} / \mathrm{ml}$. The resulted Kompos was applied directly, and resulted in fish weight increasing by $40 \mathrm{~g}$ during the first ten days of Mina Program.
\end{abstract}

Keywords : Livestock-Rice-Fish Integration, Empowerment, Ampalu 


\section{PENDAHULUAN}

Nagari Ampalu yang terletak di Kecamatan Lareh Sago Halaban Kabupaten Limapuluh Kota, merupakan lokasi pelaksanaan program. Profil Kabupaten Limapuluh Kota (2015) bentuk geografis Nagari Ampalu adalah perbukitan, lembah dan dataran, dengan luas nagari 108, $13 \mathrm{Km}^{2} \quad(27,4 \%$ dari luas kecamatan), suhu rata-rata $33^{\circ} \mathrm{C}$ dan ketinggian dari permukaan laut adalah 570 mdpl dan terdiri dari 6 jorong, yaitu: 1). Koto, 2). Padang Aur, 3). Padang Mangunai, 4). Mangunai Tinggi, 5). Guguk, dan 6). Siaur. Nagari ini sangat potensial untuk areal pertanian dan perkebunan, dimana nagari ini berada diperbukitan, dengan sumber air yang banyak. Masyarakatnya adalah suku Minang, pendidikan masyarakat setempat sudah sangat beragam, mulai dari tingkat SD hingga Diploma dan Sarjana. Namun rata-rata mata pencarian masyarakat adalah bertani, beternak dan berdagang.

Aktivitas pertanian sangatlah beragam dan tinggi. Tanaman pangan utama yang ditanam diantaranya adalah padi (merata disetiap jorong dan menjadi tanaman pertanian utama), jagung, ubi kayu, dan tanaman pangan lain yang dibudidayakan berupa sayur-sayuran. Kegiatan pertanian tersebut sangat didukung oleh lahan yang tersedia, sehingga masyarakat umumnya menjadikan pertanian sebagai mata pencarian utama. Sehingga dengan sumber daya manusia (giat bertani, melek IPTEK dan mau belajar tentang hal yang baru serta rajin mencari ilmu baru) yang ada, kegiatan pertanian dapat berjalan dengan baik. Umumnya petani di Nagari ini sudah menggunakan sistem tanam padi jajar legowo (jarwo), sudah terbiasa menggunakan alsintan dan juga ada kelompok tani yang sudah mendapatkan sertifikat "Padi Organik". Sedangkan aktivitas peternakan yang banyak terdapat di nagari ini adalah peternakan ayam petelur, sapi, kerbau, kambing dan ternak kecil lainnya yang hampir dimiliki oleh setiap rumah warga. Selain itu sumber daya alam yang juga sangat mendukung, seperti ketersediaan air yang cukup sepanjang musim (dengan sistem irigasi sederhana dan ataupun konvensional), serta RPJM Nagari 2016-2021 ditulis luas lahan persawahan sebesar 57,6\% dari total luas guna lahan.

Hal tersebut diatas melatar belakangi pelaksanaan program Integrasi Ternak-Padi-Ikan di Nagari Ampalu, dimana program ini merupakan perpaduan dari sistem peternakan, pertanian dan perikanan. Ternak akan berperan sebagai penyumbang bahan baku pembuatan pupuk organik berupa kotoran ternak, pupuk organik yang telah diolah akan dijadikan pupuk untuk padi (lahan sawah), dan ikan juga dapat memanfaatkan pupuk tersebut sebagai pakannya karena ikan dipelihara bersama dengan padi, selanjutnya ikan juga akan menyumbangkan kotorannya sebagai pupuk. Sistem ini tidak lagi membutuhkan pestisida dan pupuk kimia lainnya, jadi gabah yang dihasilkan terbebas dari bahanbahan anorganik.

Tujuan kegiatan pengabdian kepada masyarakat yang diterapkan ini adalah mentransfer IPTEK guna meningkatkan pendapatan dan kesejahteraan petani, meningkatkan pengetahuan petani akan pertanian sistem organik yang menguntungkan, pemanfaatan bahan (berupa kotoran ternak dan 
limbah pertanian) sebagai bahan baku pupuk organik serta mempertahankan kesuburan lahan.

\section{METODE PELAKSANAAN KEGIATAN}

Kegiatan pengabdian ini dilaksanakan dengan metode androgogi. Metode ini diterapkan dengan cara penyuluhan atau pemberian materi yang diikuti dengan praktek secara bersama. Diantara kegiatan yang dilaksanakan adalah 1). Penyuluhan tentang program Integrasi TernakPadi-Ikan, 2). Pembuatan mol dan pupuk organik (kompos), 3). Praktek mina padi, 4). Pemanenan.

Kegiatan dilaksanakan langsung dilahan mitra di Nagari Ampalu, dimana ikan yang digunakan untuk program mina padi adalah ikan nila dan padi yang digunakan junjuang. Data diperoleh dari hasil pengamatan serta dengan cara menyebarkan quisioner pada masing-masing respondent, selanjutnya dianalisis dan dideskripsikan.

\section{HASIL DAN PEMBAHASAN}

Kegiatan dilaksanakan selama 6 bulan mulai dari sosialisasi, praktek langsung dan evaluasi. Kegiatan ini bermitra dengan kelompok tani Anapel di Nagari Ampalu. Berdasarkan sosialisasi yang dilakukan diawal kegiatan terlihat ketertarikan mitra terhadap program ini.

\section{Pembuatan Pupuk Organik (Kompos)}

Pengetahuan mitra tentang kompos, dievaluasi dengan memberikan 14 pertanyaan (sebelum dan sesudah) kegiatan dengan mengisi kuisioner oleh 13 resondent. Rekap hasil kuisioner tentang kompos disajikan pada Tabel 1.

Tabel 1. Rekap Kuisioner Tentang Kompos

\begin{tabular}{|c|c|c|c|c|c|c|c|c|c|c|c|c|c|c|c|c|c|}
\hline \multirow[t]{2}{*}{$\mathbf{R}$} & \multirow{2}{*}{$\begin{array}{c}\text { JK } \\
(\mathbf{L} / \mathbf{P})\end{array}$} & \multirow{2}{*}{$\begin{array}{l}\text { Usia } \\
\text { (Th) }\end{array}$} & \multirow[t]{2}{*}{ Pdd } & \multicolumn{14}{|c|}{ Pertanyaan } \\
\hline & & & & 1 & 2 & 3 & 4 & 5 & 6 & 7 & 8 & 9 & 10 & 11 & 12 & 13 & 14 \\
\hline 1 & $\mathrm{~L}$ & 43 & SD & 2 & 2 & 2 & 1 & 1 & 2 & 2 & 1 & 1 & 2 & 2 & 2 & 1 & 1 \\
\hline 2 & $\mathrm{P}$ & 52 & SD & 2 & 2 & 2 & 2 & 2 & 2 & 2 & 1 & 1 & 2 & 2 & 1 & 2 & 1 \\
\hline 3 & $\mathrm{~L}$ & 48 & SLTA & 2 & 2 & 2 & 2 & 2 & 2 & 2 & 1 & 1 & 2 & 2 & 1 & 2 & 1 \\
\hline 4 & $\mathrm{~L}$ & 46 & SD & 2 & 2 & 2 & 2 & 2 & 2 & 2 & 1 & 1 & 2 & 2 & 1 & 2 & 1 \\
\hline 5 & $\mathrm{~L}$ & 49 & SLTP & 2 & 2 & 2 & 2 & 1 & 2 & 2 & 2 & 2 & 1 & 2 & 1 & 2 & 1 \\
\hline 6 & $\mathrm{~L}$ & 40 & SLTP & 2 & 2 & 2 & 2 & 1 & 2 & 2 & 1 & 1 & 2 & 2 & 2 & 2 & 1 \\
\hline 7 & $\mathrm{~L}$ & 45 & SD & 2 & 2 & 1 & 1 & 2 & 2 & 2 & 1 & 1 & 1 & 1 & 1 & 1 & 1 \\
\hline 8 & $\mathrm{P}$ & 30 & SLTP & 2 & 2 & 1 & 1 & 2 & 2 & 2 & 1 & 1 & 1 & 1 & 1 & 1 & 1 \\
\hline 9 & $\mathrm{P}$ & 43 & SD & 2 & 2 & 2 & 1 & 1 & 2 & 2 & 1 & 1 & 2 & 2 & 1 & 1 & 1 \\
\hline 10 & $\mathrm{P}$ & 45 & SD & 2 & 2 & 2 & 2 & 1 & 2 & 2 & 1 & 1 & 2 & 1 & 1 & 2 & 1 \\
\hline 11 & $\mathrm{P}$ & 47 & SD & 1 & 1 & 1 & 1 & 1 & 2 & 1 & 2 & 2 & 1 & 1 & 1 & 1 & 1 \\
\hline 12 & $\mathrm{P}$ & 50 & SD & 2 & 2 & 1 & 1 & 2 & 2 & 2 & 2 & 2 & 1 & 1 & 1 & 1 & 1 \\
\hline 13 & $\mathrm{P}$ & 50 & SD & 2 & 2 & 2 & 2 & 2 & 2 & 2 & 2 & 2 & 2 & 2 & 2 & 1 & 1 \\
\hline
\end{tabular}

Ket: $\begin{aligned} 1 & =\text { Tidak } \\ 2 & =\text { Iya }\end{aligned}$

Pertanyaan 1-4 pada Tabel 1. merupakan daftar pertanyaan sebelum dilakukan kegiatan, berupa: pengetahuan respondent tentang pupuk organik (kompos), pengetahuan tentang manfaat

kompos bagi tanaman, cara membuat kompos dan sudah pernah atau belum membuat kompos. Hasil kuisioner menunjukkan bahwa pada umumnya 
respondent sudah mengetahui dan memahami pentingnya kompos, mengetahui cara membuatnya dan sebagaian besar sudah pernah membuat kompos, kecuali beberapa respondent.

Pertanyaan yang diajukan setelah kegiatan dimulai dari pertanyaan no.5, dimana sebanyak $54 \%$ respondent menjawab tidak mengalami kesulitan dalam membuat kompos. Jawaban ini mereka berikan stelah melakukan pembuatan kompos. Sedangkan pertanyaan 6 tentang pentingnya penggunaan kompos dalam usaha pertanian dijawab $100 \%$ penting oleh responden, artinya responden sudah mengetahui pentingnya penggunaan kompos dalam usaha pertanian mereka. Akan tetapi, pertanyaan no 7 tentang peningkatan produksi padi apabila menggunakan kompos, masih ada 1 respondent yang menjawab tidak, hal ini karena respondent tersebut belum mengetahui apa itu kompos, cara membuat kompos, belum menggunakan kompos (terlihat dari jawaban yang diberikan hampir semuanya tidak (1)). Roidah (2013) menyatakan salah satu usaha yang dilakukan untuk meningkatkan kesuburan tanah adalah dengan melakukan pemupukan dengan menggunakan pupuk organik. Sutanto (2002) menambahkan, kompos ibarat multivitamin bagi tanaman, dimana sifat fisik, kimia dan biologi tanah menjadi lebih baik.

Pertanyaan tentang sudah pernah atau belum mendapatkan penyuluhan dan atau pelatihan tentang pembuatan kompos, yaitu pertanyaan no.

8. $30,7 \%$ respondent menjawab sudah pernah, pertanyaan tersebut berkaitan dengan pertanyaan no. 9, dimana respondent yang menjawab iya juga menjawab iya untuk pertanyaan no. 9. Padahal seharusnya mereka yang sudah pernah mendapatkan penyuluhan dan pelatihan, akan menjawab bahwa pembuatan kompos tidaklah sulit. Hal tersebut diduga karena program pelatihan yang diberikan sebelumnya disampaikan dengan metode yang sulit dimengerti oleh mitra. Pertanyaan terakhir tentang dampak negatif penggunaan kompos, $100 \%$ respondent mengetahui tidak ada dampak negatif, bahkan penggunaan kompos sangat bermanfaat bagi kesuburan tanah dan produktivitas hasil panen. Zulkarnain, M., Prasetya, B dan Soemarno (2013) menyatakan, penggunaan kompos, pupuk kandang dan custom-bio dapat meningkatkan kandungan C-Organik dan N-Total dalam tanah, sehingga meningkatkan hasil panen tebu.

Berdasarkan kegiatan yang telah dilaksanakan, mitra sudah mengetahui bahan yang digunakan dan memahami cara pembuatan kompos dengan baik termasuk mol (starter) dari kompos itu sendiri. Adapun bahan yang digunakan dalam pembuatan mol dan jumlah angka lempeng total pada mol disajikan pada tabel 2.

Tabel 2. Bahan Pembuatan Mol dan Jumlah ALT pada Mol

\begin{tabular}{l|c}
\hline \multicolumn{1}{c|}{ Komposisi Bahan } & Jumlah \\
\hline Air Kelapa (buah kelapa) & 1 \\
\hline Air cucian beras (ml) & 500 \\
\hline Rebung $(\mathrm{g})$ & 300 \\
\hline Kulit Nanas $(\mathrm{g})$ & 500 \\
\hline Buah busuk/limbah buah $(\mathrm{g})$ & 500 \\
\hline Gula merah $(\mathrm{g})$ & 250 \\
\hline ALT $(\mathrm{CFU} / \mathrm{ml})$ & $1,0 \times 10^{10}$ \\
\hline
\end{tabular}

ALT (Angka Lempeng Total) merupakan jumlah total mikroorganisme yang terdapat pada mol atau starter, hal ini menunjukkan sejumlah mikroorganisme yang akan bekerja selama pengomposan. Seperti diketahui bahwa kompos merupakan hasil dari aktivitas atau perombakan atau penguraian oleh sejumlah mikroorganisme. Andy (2010) menjelaskan bahwa kompos merupakan hasil penguraian bahan-bahan organik yang dapat dipercepat oleh populasi berbagai 
macam mikroorganisme dalam kondisi lingkungan yang hangat, lembab, aerobik dan anaerobik.

Starter mengandung sejumlah mikrobia yang sangat diperlukan dalam proses pengomposan. Mikroba starter yang baik adalah yang dapat menurunkan jumlah mikroba patogen dalam bahan. Pada proses pengomposan peningkatan suhu dapat meningatkan germinasi spora pathogen, selanjutnya bakteri pathogen akan sepenuhnya mati. Karena mikroba pathogen akan mati pada suhu thermofilik, yaitu suhu $60-70{ }^{\circ} \mathrm{C}$. Kemudian suhu dipermukaan (lebih kurang mulai dari $20 \mathrm{~cm}$ dari permukaan), belum sepenuhnya mencapai suhu thermofilik, sehingga proses pengomposan memerlukan pembalikan yang bertujuan untuk menciptakan suhu thermofilik yang merata pada semua bahan (kompos) (Agus, Faridah, Wulandari dan Purwanto, 2014).

Gaur (1983), penggunaan oksigen dalam proses pengomposan terbagi menjadi 2 proses yaitu secara aerob dan anaerob. Pengomposan secara aerob adalah selama proses pengomposan terdapat oksigen yang terlibat selama proses dekomposisi oleh bakteri. Reaksi proses aerob terjadi sebagai berikut:

Bahan organik+O2+bakteri $\rightarrow \mathrm{CO}_{2}+\mathrm{NH}_{3}+\mathrm{Humus}+$ Energi+Air Sedangkan reaksi proses anaerob terjadi tanpa adanya oksigen yang terlibat selama proses dekomposisi, prosesnya sebagai berikut:

Bahan organik+bakteri $\rightarrow \mathrm{CO}_{2}+\mathrm{NH}_{3}+\mathrm{Humus}+$ Energi+Air $+\mathrm{H}_{2} \mathrm{~S}+\mathrm{CH}_{4}$ Adapun mekanisme pengomposan secara umum disajikan pada gambar 1 berikut

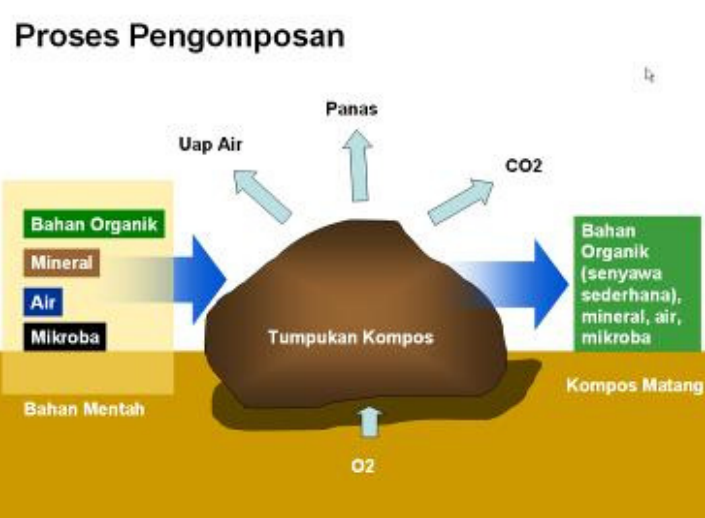

Gambar 1. Mekanisme pengomposan secara umum (wikipedia.org)

Bahan yang digunakan dalam pembuatan kompos sebaiknya adalah limbah pertanian yang mudah didapat. Diantara bahan yang digunakan dalam kegiatan ini adalah kotoran hewan (ternak), tanaman titonia, limbah pertanian (jerami), dedak padi, air gula merah dan stater.

\section{Program Mina Padi}

Mina padi merupakan suatu bentuk usaha tani gabungan (combained system) yang memanfaatkan genangan air sawah yang ditanami padi sebagai kolom untuk budidaya ikan air tawar. Ikan yang biasa digunakan dalam program ini adalah ikan tawes, ikan nila, ikan mas, dsn sebagainya. Namun beberapa jenis ikan yang paling baik dipelihara adalah: ikan nila, ikan bawal air tawar, ikan mas dan ikan mujahir. Hal ini karena jenis ikan tersebut mampu bertahan pada air dangkal dan sinar matahari (Siregar, 2016).

Keuntungan yang diharapkan dari program ini adalah keuntungan ganda, berupa hasil dari tanaman padi dan hasil dari ikan itu sendiri. Akan tetapi ada keuntungan lain yang dapat diperoleh dari program ini adalah dapat meningkatkan kesuburan tanah (lahan sawah), dimana kotoran ikan dapat dimanfaatkan sebagai pupuk oleh padi, dapat mengurangi hama dan penyakit tanaman (padi) (Siregar, 2016). 
Gambar 2. tentang layout pada lahan mina padi, dimana lebar kolam $50 \mathrm{~cm}$ dan kedalaman $30 \mathrm{~cm}$. Abidin (2016), menjelaskan selama pembudidayaan sebaiknya genangan air tetap terjaga $15 \mathrm{~cm}$ pada lahan sawah dan $30-40 \mathrm{~cm}$ pada kolam. Sehingga dengan kedalam $50 \mathrm{~cm}$ diharapkan air genangan tetap bisa dijaga. Program ini menggunakan ikan nila dan padi junjuang. Ikan dilepas pada hari ke-3 setelah padi ditanam, dimana sebelumnya sawah sudah dirancang sedemikian rupa guna membuat kolom ikan. Kegiatan ini mengkondisikan sistem penanaman padi dengan jajar legowo. Pemanenan ikan dapat dilakukan sebelum padi dipanen, yaitu waktu sebelum genangan air sawah dikeringkan, atau bisa juga dikondisikan dengan ukuran ikan yang telah dihasilkan. Gambar 2 berikut layout lahan mina padi.

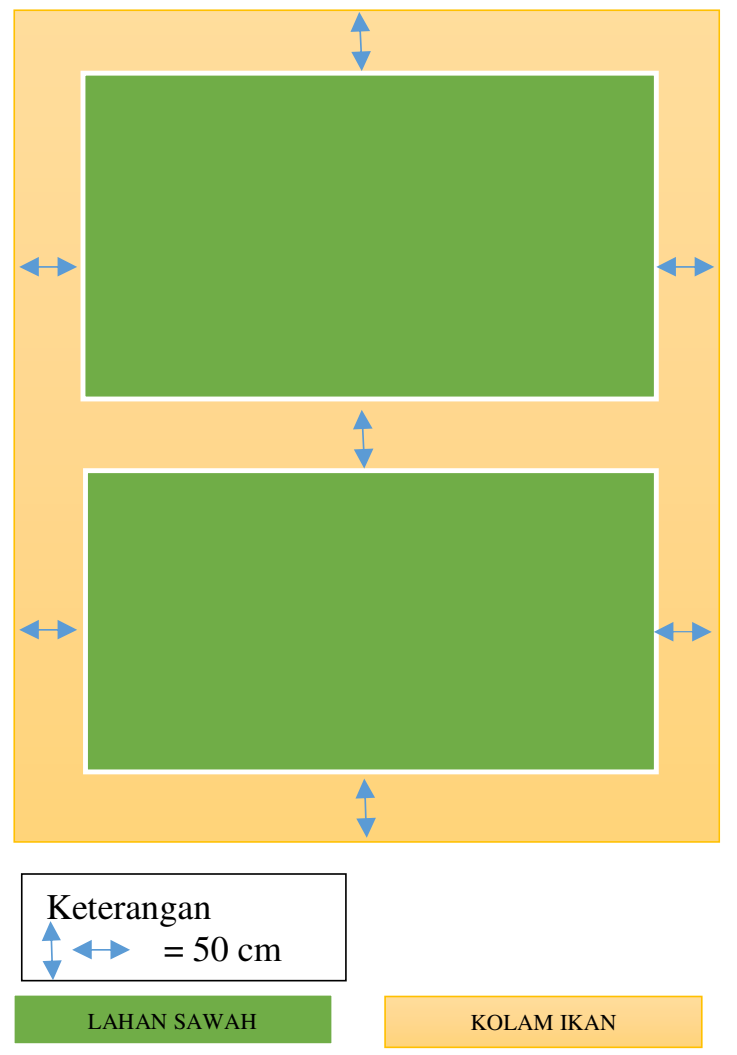

Gambar 2. Layout Lahan Mina Padi

Gambar 2. diatas menggambarkan tentang letak kolam dan lahan sawah yang digunakan pada program mina padi. Pemahaman dan ketertarikan mitra dengan program ini dievaluasi dengan memberikan pertanyaan dalam bentuk quisioner (tabel 3).

Quisiner terdiri dari 9 pertanyaan yang diikuti oleh 13 respondent, karena program pengomposan merupakan bagian dari proram integrasi ternak-padi-ikan, sehingga panelis yang digunakan juga sama. Pertanyaan pertama mengenai pemahaman respondent tentang program mina padi, dimana $77 \%$ respondent menjawab belum mengetahui tentang program mina padi, sehingga diperlukan penyuluhan dan sosialisasi tentang program mina padi ini. Oleh karena belum adanya pemahaman tentang program ini, respondent juga belum mengetahui manfaat yang bisa diperoleh dengan program ini. Hal ini tergambar dari pertanyaan no.2, selanjutnya untuk pertanyaan mengenai penerapan program mina padi sebelum dilakukan sosialisasi, penyuluhan dan paktek, mitra juga belum mengetahui bagaimana penerapannya. Karena berdasarkan jawaban no.4 respondent belum menerapkan program ini. Setelah dilakukan praktek, $23 \%$ respondent menjawab sulit untuk dilakukan program ini. Namun pada soal no.6, $100 \%$ respondent menjawab program ini dapat meningkatkan penghasilan petani.

Pertanyaan no.7 mengenai kendala dalam penerapan program ini, $23 \%$ respondent menjawab iya ada kendala, semuan menjawab kendai yang mungkin akan dihadapi adalah mengenai adanya predator ikan. Respondent takut kalau predator ini akan merusak tanaman padi mereka juga. Pertanyaan no. 8 mengenai apakah respondent sudah pernah mengikuti penyuluhan sebelumnya, $23 \%$ respondent menjawab sudah pernah. Pertanyaan terakhir mengenai hasil 
praktek, apakah diterapkan menurut prosedur mengikuti prosedur yang telah diberikan. Tabel yang sebenarnya, ternyata ada $23 \%$ panelis tidak hasil quisioner mina padi disajikan pada tabel 3 .

Tabel 3. Rekap Kuisioner Mina Padi

\begin{tabular}{|c|c|c|c|c|c|c|c|c|c|c|c|c|}
\hline $\mathbf{R}$ & JK & Usia & Pdd & \multicolumn{7}{|c|}{ Pertanyaan } \\
\cline { 5 - 12 } & $(\mathbf{L} / \mathbf{P})$ & $(\mathbf{T h})$ & & $\mathbf{1}$ & $\mathbf{2}$ & $\mathbf{3}$ & $\mathbf{4}$ & $\mathbf{5}$ & $\mathbf{6}$ & $\mathbf{7}$ & $\mathbf{8}$ & $\mathbf{9}$ \\
\hline 1 & $\mathrm{~L}$ & 43 & SD & 2 & 2 & 2 & 1 & 1 & 2 & 1 & 2 & 2 \\
\hline 2 & $\mathrm{P}$ & 52 & SD & 1 & 1 & 1 & 1 & 2 & 2 & 2 & 1 & 2 \\
\hline 3 & $\mathrm{~L}$ & 48 & SLTA & 2 & 2 & 1 & 1 & 1 & 2 & 1 & 2 & 2 \\
\hline 4 & $\mathrm{~L}$ & 46 & SD & 1 & 1 & 1 & 1 & 1 & 2 & 1 & 1 & 1 \\
\hline 5 & $\mathrm{~L}$ & 49 & SLTP & 2 & 2 & 1 & 1 & 1 & 2 & 1 & 2 & 2 \\
\hline 6 & $\mathrm{~L}$ & 40 & SLTP & 1 & 1 & 1 & 1 & 1 & 2 & 1 & 1 & 2 \\
\hline 7 & $\mathrm{~L}$ & 45 & SD & 1 & 1 & 1 & 1 & 1 & 2 & 1 & 1 & 2 \\
\hline 8 & $\mathrm{P}$ & 30 & SLTP & 1 & 1 & 1 & 1 & 1 & 2 & 1 & 1 & 2 \\
\hline 9 & $\mathrm{P}$ & 43 & SD & 1 & 1 & 1 & 1 & 1 & 2 & 1 & 1 & 2 \\
\hline 10 & $\mathrm{P}$ & 45 & SD & 1 & 1 & 1 & 1 & 1 & 2 & 1 & 1 & 2 \\
\hline 11 & $\mathrm{P}$ & 47 & SD & 1 & 1 & 1 & 1 & 1 & 2 & 1 & 1 & 2 \\
\hline 12 & $\mathrm{P}$ & 50 & SD & 1 & 1 & 1 & 1 & 2 & 2 & 2 & 1 & 1 \\
\hline 13 & $\mathrm{P}$ & 50 & SD & 1 & 1 & 1 & 1 & 2 & 2 & 2 & 1 & 1 \\
\hline
\end{tabular}

Ket: $1=$ tidak, $2=$ iya

\section{KESIMPULAN}

a) Kesimpulan dari kegiatan ini adalah, mitra sangat tertarik dengan program yang diberikan dan berpartisipasi aktif selama kegiatan. Pelaksanaan program berjalan sesuai dengan yang direncanakan, pertambahan bobot ikan pada sepuluh hari pertama setelah dilepas membangkitkan semangat mitra untuk melaksanakan program ini. b) Kebutuhan masyarakat Ampalu (mitra) dengan program ini dirasa sangat tepat, karena masyarakat Ampalu merupakan masyarakat yang mudah menyerap teknologi. Nagari Ampalu juga merupakan nagari yang masyarakatnya aktif bertanam padi (bersawah). c) Kegiatan ini bermanfaat demi peniggkatan pendapan petani padi di Nagari Ampalu, karena mereka akan mendapakan 2 keuntungan sekaligus, dari panen ikan dan produksi padi yang juga lebih baik dan lebih banyak. d) Direkomendasikan kepada pengabdi yang berminat bermitra dengan masyarakat Ampalu untuk tetap menginroduksikan IPTEK yang berkaitan dengan budidaya dan pasca panen padi.

\section{SARAN}

Kegiatan selanjutnya disarankan untuk membuat perbandingan antara kelompok yang telah berhasil menjalankan program dengan kelompok yang masih dalam tahap belajar mengaplikasikan program ini.

\section{UCAPAN TERIMAKASIH}

Terimakasih penulis dan tim ucapkan kepada DRPM Dikti yang telah memberikan bantuan dana pelaksanaan kegiatan KKN-PPM tahun pelaksanaan 2017. Wali nagari dan staf serta masyarakat Nagari Ampalu yang telah memberikan dukungan demi terlaksananya program ini 


\section{REFERENSI}

1. Abidin, Z. 2016. Teknik Budidaya Ikan dengan Mina Padi.

http://www.tipsikan.blogspot.co.id

2. Agus, C., Faridah, E., Wulandari, D dan Purwanto, B.H. 2014. Peran Mikroba Starter dalam Dekomposisi Kotoran Ternak dan Perbaikan Kualitas Pupuk Kandang. Jurnal Manusia dan Lingkungan. Vol.21, no.2: 179-187

3. Andy. 2010. Buku Kompos. http://andyjalur.files.wordpress.com

4. Gaur, A.C. 1983. Manual of Rural Composting. Rome: Food and Agricultural Organization of The United Nation

5. Kabupaten Limapuluh Kota. Profil Daerah. http://www.limapuluhkotakab.go.id/profi 1. Diakses 2 Maret 2015

6. Lantarsih, L. 2016. Pengembangan "Mina Padi Kolam Dalam" di Kabupaten Sleman. Jurnal Agraris. Vol. 2, no.1. 1727
7. Murbandono, L. 1983. Membuat Kompos. Penebar Swadaya. Jakarta

8. Roidah, I.S. 2013. Manfaat Penggunaan Pupuk Organik untuk Kesuburan Tanah. Jurnal Universitas Tulungagung Bonorowo. Vol.1, no.1: 30-42

9. Siregar, A.Z. 2016. Teknologi Budidaya Ikan Nila (Oreochromis niloicus) dan Gurami (Osphronemus gouramy) di Lahan Padi Pasang Surut. Skripsi Universitas Sumatera Utara. Medan

10. Sutanto, R. 2002. Penarapan Pertanian Organik (Pemasyarakatan dan Pengembangannya). Kanisius. Yogyakarta.

11. Zulkarnain, M., Prasetya, B dan Soemarno. 2013. Pengaruh Kompos, Pupuk Kandang dan Custom-Bio terhadap Sifat Tanah, Pertumbuhan dan Hasil Tebu (Saccharum officinarum, L) pada Entisol di Kebun NgrangkahPawon, Kediri. Indonesia Green Technologi Journal. E-ISSN. 2338-1787. Vol. 2. No. 1: 45-52 